\title{
Critical success factors (CSFs) for motivating end-user stakeholder's support for ensuring sustainability of PPP projects in Nigerian host communities
}

\author{
Luqman Toriola-Coker, Yaba College of Technology, Yaba, Nigeria \\ Hakeem Owolabi, University of the West of England - Frenchay Campus, \\ Bristol, UK \\ Hafiz Alaka, University of Hertfordshire, Hatfield, UK \\ Wasiu Adeniran Bello, Department of Quantity Surveying, University of \\ Lagos, Lagos, Nigeria \\ Chaminda Pathirage, University of Wolverhampton, Wolverhampton, UK
}

\begin{abstract}
Purpose - This study aims to investigate two public private partnership (PPP) road projects in Nigeria for exploring factors that can motivate end-user stakeholders for contributing towards sustaining a PPP project in the long-term.

Design/methodology/approach - Using a case study methodology approach, this study adopts twoway data collection strategies via in-depth interviews with PPP experts and end-user stakeholders in Nigeria host communities and a questionnaire survey to relevant stakeholders.

Findings - The study identifies an eight-factor structure indicating critical success factors for ensuring enduser stakeholders support PPP projects on a long-term basis in their host communities.

Originality/value - Results of the study have huge implications for policymakers and project companies by encouraging the early integration of far-sighted measures that will promote long-term support and sustainability for PPP projects amongst the end-user stakeholders.
\end{abstract}

Keywords: Nigeria, Sustainability, Road projects, Public private partnership, End-user stakeholders

\section{Introduction}

The procurement of public infrastructures such as prisons, roads, schools, rail tracks and train systems, electricity amongst others, through public private partnership (PPP) arrangements has been a major challenge for Nigeria, despite been used successfully in other parts of the globe in the past two decades (Toriola-Coker et al., 2020). According to Delmon (2017), many countries have sustainably developed guidelines, policies and frameworks to successfully realise the implementation of infrastructure projects using the PPP model. However, despite early positive strides, Nigeria remains beset by several infrastructure procurement problems, a key aspect of which is "how to sustain the executed PPP projects"- despite the extensive human and material resource investment (Babatunde et al., 2016). Evidence from earlier studies like Sanni (2016), Babatunde et al. (2016) and Owolabi et al. (2019) have shown that many PPP projects in Nigeria face difficult challenges recouping their investments, especially where the user-pay approach has been used. 
Apart from the politicisation of contracts, less transparent and pseudo competitive bidding process, including land ownership problems; stakeholder opposition to PPPs in Nigeria remain considerably high (Owolabi et al., 2019). According to Toriola-Coker (2018), sustaining the smooth running of many critical PPP projects in the country has been a major challenge due to the neglect of project end-users and the need for their participation in the project delivery process (Toriola-Coker, 2018). As suggested by Owolabi et al. (2019), the social acceptability of PPP projects appears considerably low as most PPP policy decisions and implementation programmes have adopted a top-down approach. Many PPP projects such as the Lekki-toll gate in Lagos amongst others, face threats to their long-term profitability and sustainability due to the mismanagement of end-users (i.e. commuters, drivers, local residents, etc.) by the government, thus resulting in several protests and vandalism.

As corroborated by Sathyasheel and Deepak (2017), a critical factor contributing to the failure of many Nigerian PPP initiatives and their inability to sustain the benefits of PPP projects is the divergence between end-user expectations and public sector interests on PPP projects. Previous researchers have documented how end-user stakeholders have been sidelined and their opinions relegated, which consequently affects the long-term operational sustainability of many of Nigeria's early PPP projects (Amadi et al., 2014; Owolabi et al., 2019; Toriola-Coker et al., 2020). In the context of this study, we describe sustainability as the long-term maintainability of the operational and physical aspects of PPP projects in a way that helps deliver long-term anticipated benefits and goals (Owolabi et al., 2020). Evidence from prior literature such as Owolabi et al. (2019); Toriola-Coker et al. (2020) have highlighted how a number of Nigeria's PPP projects have encountered end-user opposition, not only from environmental and social pressure groups and the media but also from community stakeholders', due to issues such as unwillingness to pay for toll roads, protest over community lands; environmental damage during project construction (Toriola-Coker, 2018). According to Toriola-Coker (2018), this limited involvement and engagement of project end-users have led to general apathy and lack of sense of ownership for projects at community levels; thereby negatively impacting on the long-term maintainability of these flagship PPP projects.

Arguing on the need for better end-user engagement for Nigeria's PPP delivery, Amadi et al. (2014), highlighted the growing concern over the sustainability practices of end-user stakeholders on Nigeria's first PPP road project. Similarly, Toriola-Coker further highlighted pressing challenges such as environmental impact, benefit realisation and low community-level participation amongst other impediments that are militating against the smooth operations of the PPP project in Nigeria (Toriola-Coker, 2018). This argument has been further buttressed by Oyedele (2012a, 2012b), who argued that Nigeria still lacks the operational capability to push many PPP projects through to success. However, these shortcomings are in contrast to PPP delivery in other countries (i.e. UK, Germany, The Netherlands, Spain, Italy and France) where robust mechanisms are in place for bringing all relevant and important players on board to deliver and sustain PPP projects (Fatokun et al., 2015). 
Given the prevalent poor end-user stakeholder's engagement practices in many of Nigeria's PPP projects and the resultant obstacle to their successful growth (Du et al., 2018); studies have, therefore, called for more attention from policy formulators, government and PPP practitioners to do more in ensuring better engagement with PPP end-users to gauge their perception, awareness and interest. Owolabi et al. (2020) argued that this approach will encourage and lead to improvement in the sense-of-belonging and communal ownership of projects amongst end-users; with regular interactions between communities and project organisations also helping to diffuse tensions and resolve confusions (Freeman, 2010). Nevertheless, whilst Nigeria's challenges regarding the end-users role in sustaining PPP projects over the longer term persist (Toriola-Coker, 2018); various researchers have done extensive studies on stakeholder management in PPP (Ogunsanmi, 2013; Amadi et al., 2014; Osei-kyei and Chan, 2017, 2018). However, most of these studies have either concentrated on stakeholder issues in foreign countries such as UK, Australia, India, China, Indonesia, France and Brazil (Lv and El-Gohary, 2016; Hill Chung et al., 2010; Harris, 2010; Akintoye et al., 2011). The foreign context of these studies vis-à-vis the unique nature of African PPPs; and Nigeria, in particular, has undermined the wider applicability of most of these findings. In addition, whilst a lot of studies have also investigated end-users stakeholder management in Nigeria's PPPs (Toriola-Coker, 2020; Owolabi et al., 2020; Oyedele, 2012a, 2012b), there is currently no literature investigating the critical role of community-level end-users in the long-term sustainability of PPP projects located within their communities. This, therefore, represents a huge gap in the existing body of literature, which this study intends to fill. Hence, the overall aim of this study is to investigate the critical roles and factors affecting end-users stakeholders contribute to the long-term sustainability of PPP projects in their communities, using a case study of two PPP road projects in Nigeria". To effectively examine this research aim, the following research questions will be asked and addressed in the study:

RQ1. To investigate the challenges of PPP delivery in Nigeria and the marginalisation of end-users stakeholders using two PPP toll roads projects in Lagos, Nigeria as case studies.

$R Q 2$. To Investigate the critical role, impact and contributions of end-users towards successful delivery and long-term sustainability of PPP projects in local communities.

$R Q 3$. To identify the top key strategies for improving end-users role and contribution towards the long-term sustainability of PPP projects in Nigerian communities.

Significance of the study: This study has huge significance as it addresses the problems of end-user stakeholder opposition to PPP projects in Nigerian host communities. The study evaluates and identified critical factors that can enable the active involvement of end-user stakeholders towards promoting the long-term sustainability of PPP projects in their local communities.

\section{Literature review}

\subsection{Evolution of public private partnership projects in Nigeria and contextual challenges}

Despite the progress being made in Nigeria, with a current population of over 140 millionand an annual growth rate of 2.4\% (National Planning Commission, 2004), Nigeria still hasdaunting challenges with the delivery of essential public infrastructural facilities and basicamenities. This suggests the huge task ahead of Nigeria in terms of infrastructural 
challenges (Ibrahim et al., 2006). Although various efforts have been made in terms of enormous infrastructure investment by previous governments, socio-economic developments have continued to be elusive. Recently, suggested reports have shown that the country needs between US $\$ 12$ bn to US $\$ 15$ bn yearly for a protracted period of six years to fulfil the standard infrastructural requirements (Toriola-Coker, 2020; Owolabi et al., 2020).

Against all the various infrastructural challenges faced by Nigeria, the popularity of PPP is, however, on the rise, especially in the area of roads construction, markets, estates, car parks including managing and operating of old infrastructural facilities such as conference centres (Abdul-Aziz, 2001; Levy, 1996; Ogunlana, 1997). In the past 10 years, over N10tn has been invested by the Federal, State and Local administration through PPPs in over 25 major infrastructural projects. This is inspite of the targeted N32tn investments in infrastructural facilities for achieving the country's vision 2020 (Alitheia, 2010). In furtherance to this developmental target, the Federal Government of Nigeria did put in place a number of enabling laws to regularise all contractual arrangements of PPP including the national policy on PPP, Infrastructure Concession Regulatory Commission (ICRC) Act of 2005; Public Procurement Act 2015; National Integrated Infrastructure Master Plan, etc. These laws are intended to facilitate the effective implementation of projects and private sector collaboration. As highlighted by Olusola et al. (2012), there is currently growing support and political will from the Nigerian Government at all levels towards developing the PPP as a mainstream procurement policy.

Perhaps the success story in Lagos state aptly exemplifies the huge strides that Nigeria is gradually making in PPP. Notably, the Lagos State Government kick started the introduction of PPP in Nigeria with the passage into Law of the Lagos State Roads, Bridges and Highway Infrastructure Development Board (2004). This infrastructure law, which has been supplemented with other procurement laws and compiled into what is now regarded as the Lagos State Public Procurement Law 2011, provides a framework for private sector involvement in the delivery of public infrastructures. Currently, Lagos State has implemented PPP procurement routes in various sectors such as power generation, maintenance of highways, waste disposal management amongst others. The successful implementation of these laws in the state has led to increased cooperation between private investors and the state government; and has yielded numerous dividends in the grey areas of infrastructural provisioning (Global legal group, 2007). However, whilst all might seem rosy on the surface for PPP development and delivery in Nigeria. New and emergent issues are pointing towards a challenging time for the government on PPPs, especially as it relates to the social acceptability of the PPP model and the end-user opposition and violence (Toriola-Coker, 2020).

For instance, the recent ENDSARS protest and the destruction of the Lekki Toll gates in Lagos Nigeria, amongst several other similar protests have provided clearer perspectives regarding end-users stakeholders' opposition towards PPP projects and the government as a whole. The protest which started as a protest against police brutality later culminated in the destruction of all the toll points, the infrastructure and the technology at the Lekki PPP tollgate due to end-users grievances against the Government. Other factors affecting PPP in Africa, according to Fatokun et al. (2015) are also weak credit-rating of many indigenous PPP sponsors usually give rise to sponsor risk, thus hindering their capacity to attract viable project partners (Mills, 2010). From foreign financiers' perspective, weak credit capacity of indigenous project sponsors discourages lenders from financing or compels them to reduce the size of the loan to invest in a project' (Owolabi et al., 2020). In addition, other country-related challenges such as civil unrest, currency devaluation, leadership instability and weak legal framework for PPP, can also present real threats of political risk, 
thus making African PPP unattractive to many investors (Bing et al., 2005; Carrieri et al., 2006; Busse and Hefeker, 2007). According to Kayaga (2008), expropriation and government repudiation of contracts are seriously limiting Africa's PPP growth, with $80 \%$ of PPP contracts attracting disputes and cancelled between 1990 and 2004. Such cancellations will have a negative impact on a nation's PPP initiative and dampen market confidence in the government's commitments (Ncube, 2010). Hence, researchers have argued for a more robust strategy in solving the end-user stakeholders' crisis to ensure project investments last longer and deliver intended benefits to communities (Lv and El-Gohary, 2016; Hill Chung et al., 2010; Harris, 2010; Akintoye et al., 2011).

\subsection{Sustainability of public private partnership projects and the role of end-users stakeholders' in developing economies (Nigeria)}

Construction and maintenance of public infrastructures in developing economies like Nigeria are persistently yearning for sustainability (Zawawi et al., 2014). Sustainability has become such a catchword that can be described as in perpetuity or lasting approach to fortification (Bai et al., 2017). The perception of maintainability in the current body of knowledge concerns not only environmental protection but also other components of sustainability, including social and economic sustainability, which cannot be ignored. As such, therefore, the concept of sustainability has been considered as a holistic and integrative approach to keep a balance between the three components of social, environmental and economic (Tunji-Olayeni et al., 2020). For PPP projects, huge capital investments are typically needed for its execution. Two significant reasons for setting PPP procurement procedure different from traditional procurement method are established by some researchers (Carbonara et al., 2016; Amadi, 2017) including as follows: ensuring much stronger competition to improve infrastructure quality and value for money and - the satisfaction of end-user stakeholders vis-à-vis their communities.

As the PPP model helps facilitate the delivery of public infrastructure facilities including roads, bridges, residential, power amongst others, there is an increasing but not necessarily positive impact on the economy, environment and society. Therefore, the balance between the three components of sustainability plays a significant role in the delivery of PPP projects. As, in PPPs, it is strongly recommended that the policymakers recognise the significance of end-user stakeholder's participation based on the triple-bottom-line, rather than the traditionally used measures focussing on time, cost and quality. This perspective has been corroborated by a paper delivered by Olson and Swenson (2011) and Xiao et al. (2013) during a construction conference in North America, where end-user stakeholders' critical role in PPP has been considered to be largely marginalised. Hence, it is important to do more research on end-user stakeholder's sustainability in any PPP road construction project (Mwakabole et al., 2019).

According to Toriola-Coker et al. (2020), End-user stakeholders are described as the regular users of any infrastructure facilities. Unfortunately, most PPP end-users in developing nations like Nigeria have their wishes and desires yet to be fulfiled, especially as most remain unenlightened on the significance of sustaining such projects, as well as practices and procedures for ensuring long-term sustainability on projects (Ke, 2017). Various sustainability-assessment tools and methods have been introduced, particularly by advanced countries to assess the level of end-users stakeholders' performance in terms of adherence. For instance, in the UK, the Building Research Establishment Environmental Assessment Method was the first method for rating, assessing and certifying the sustainability of end-user stakeholders on infrastructure facilities (Whang and Kim, 2015). This is based on an overall score of the pass, good, very good, excellent and outstanding. 
Failure to comply will arise to unprofessional behaviour, weak enforcement mechanisms, self-interest and inefficient regulatory frameworks amongst others (Mwakibinga and Buvik, 2013). The International Initiative for a Sustainable Built Environment developed the SBTool assessment method to rate the sustainability performance of end-user stakeholders, which focusses on the environmental, economic and social aspects of sustainability (Hashim et al., 2020). The tools were able to assess and rate the performance in accordance to the awareness initiated by the private investors and government.

However, inadequate planning for end-user stakeholder in most of the developing country like Nigeria is a contributing factor to the mostly proposed PPP projects which continues to become more complex (Toriola-Coker et al., 2020). The revelation came through a literature review that philosophy that keeps on encouraging the involvement of "citizen" such as end-user stakeholders is when the procurement officers requested contractors' adherence to the participation of end-user stakeholders in design, planning and operation of infrastructure facilities (Arnstein, 2015). This involvement has been demonstrated in the hierarchy of citizen participation that was established by Arnstein (2015) in which end-user stakeholders' participation must be in terms of control, power information and manipulation between the community and government. This is described by using a ladder chart as a symbol for growing access to managing power as depicted in Figure 1. These uphold their professional integrity and ethical code which demonstrates the general integration between community and government in power sharing, policy decision-making and preparation stages (Abel et al., 2013; Mwelu et al., 2018).

On the other hand, the commitment of all end-user stakeholders is mandatory to achieve sustainable practice. As the large variety of actors and the complexity of their interactions are predetermined, the end-user stakeholders' involvement and participation can be enhanced through liberal awareness of the sustainable practice. Myers (2005) reviewed the practices to sustainability by the end-user stakeholders in the UK based on public disclosures and concluded that remarkably above the average of end-user stakeholders embrace sustainability and relatively few developing countries have changed the level of awareness of end-user stakeholders on sustainability. Realising the anticipated or targeted benefits from PPP projects, end-user stakeholders through literature review shows some intimidating challenges on sustainability during and after project completion (Akintoye et al., 2011). From the literature review, the challenges encountered on economic benefit, environmental impact, benefit Realisation and community participation by end-user stakeholders on sustainability are subsequently discussed.

\subsection{Community impact benefits}

The community impact benefits are special effects that PPP road projects have on neighbouring communities, apart from those deliberately sustaining the direct users and travellers of transportation services (Greenfield et al., 2015). They are frequently called community impacts or social impacts (Scharlach, 2012) because of their sustainable effects on neighbourhood liveability (the quality of residents that work, live or visit the environment) as a result of changes in views, noise, land use mix, walking environment and community unity i.e. the quality of communications amongst fellow neighbours (Appleyard et al., 2014). Associated impacts on property values can also be involved (Greenfield, 2015) and divergence impacts on vulnerable population groups cannot be ignored. Academic researchers (Greenfield et al., 2015; Norouzian-Maleki et al., 2015; Walden, 2015) sighted some examples on how community impacts can influence end-users stakeholder's interests as follows: 
- Improve walking and cycling conditions in an environment and integrating landscapes such as pocket parks and walkways.

- Create opportunities for neighbours to interact with each other thereby increasing community unity.

- New road configuration creates an opening in locating markets, shops and offices in a dejected neighbourhood because of developments to get easy access and safety i.e. the effect on property and land use

- Creation of bus terminals reduces the effect of rainfall and sunlight, humanizing the views of the neighbourhood (visual effect).

All these mentioned impacts will create economic benefits for the end-user living along with the neighbourhood of the project.

\section{Research methodology}

To examine the research problem within the real-world setting, this study adopted a multiple-case study strategy. From the perspective of Creswell (2007), case study methodology involves examining a research problem through one or numerous cases in a confined system. This strategy, the study believed will allow multiple perspectives to be explored, thereby enriching the research findings (Baxter and Jack, 2008). On this basis, the study selected the as follows:

- Lekki-Epe PPP project and

- Apakun Muritala Muhammed PPP project as convenient case studies for investigating the research problem.

Whilst the Lekki Epe project is located under the Ibeju Lekki Local Municipal or local government; the Apakun project is located under the Lkeja Local Government municipal. However, both projects are located in Lagos State, Nigeria. Mixed research methods including in-depth interviews (qualitative) and questionnaire survey (quantitative) were adopted to investigate this study because it promotes a combination of methods that proffers the best solutions to research questions (Johnson and Gray, 2010). It also accommodates multiple methods of data collection and triangulation within a single study and avoids common weaknesses in either approach (Zhang et al., 2013). Hence, this study leverages the exploratory sequential mixed method by first conducting In-depth interviews with experts on PPP projects who worked as staff during the implementation and operation of the PPP road projects. Qualitative data from the interviews were then analysed and later used to develop a questionnaire survey. This is then immediately followed with the distribution of a questionnaire survey of regular road users (commuters, drivers, transport union officials, private car owners and local communities in Lagos State, Nigeria. This, therefore, helped to obtain relevant quantitative data from the end-user stakeholders, especially those who are present during the implementation and operation of the case study PPP projects. Table 1 presents the characteristics of respondents that participated in the unstructured interview.

\subsection{Phase-1}

The first phase of the study involved unstructured interviews with experts in infrastructure project development and PPP implementation in Nigeria. The interviews were conducted over a period of 9-weeks between April 2019-June 2019. In all, nine in-depth interviews were conducted with experts. The aim of the interview was to identify the challenges each 
respondent encountered that may threaten the long-term sustenance of the PPP project in their locality. The interviews were recorded using a digital recorder. Nvivo-12 software was used to transcribe and analyse the interview data. Using Thematic Analytical Technique, the study uncovered various implicit and explicit underlying end-users discontent and factors that may jeopardise the long-term sustainability of PPP projects in their local communities. Word frequency was also used to quickly identify potential codes before indepth text reading and all words relating to a potential factor in the word frequency query search were noted and coded as well. Kindly see extracts of the thematic analysis codingscheme in Table 2 below.

\subsection{Phase-2}

The Phase- 2 of the study involved a questionnaire survey to wider audiences of end-users of the identified PPP projects in Lagos, Nigeria. Due to the absence of a uniform and publicly available database for survey respondents, a snowball sampling approach was used to recruit questionnaire respondents amongst end users of the PPP road projects. The questionnaire respondents included members of projects' host communities, commercial transporters i.e. drivers, passengers, transport union officials and workers, land-lords in local communities and other private road users (personal cars, trucks, etc.). A total of 150 questionnaires were distributed by hand to respondents over a period of 6 months from August 2019 to January 2020. Consequently, a total of 98 questionnaires were filled and returned suggesting about $65 \%$ of the distributed questionnaire being successfullyreturned. The questionnaire data was extracted and processed using a blend of excel sheets and SPSS software. Using the SPSS tool, series of statistical analyses were performed on the extracted questionnaire data.

\section{Results and data analysis}

This section presents the results of qualitative and quantitative data analysis from the study. Based on the thematic analysis conducted on the interview data, the study examined the underlying themes in the data and presented the coding scheme in Table 2 below.

Based on the thematic analysis, the study identified 33 end-user-related factors for ensuring the long-term sustainability of PPP projects in host communities. Table 3 below presents the end-users-related factors for ensuring the sustainability of PPP projects in host communities.

\subsection{Statistical analysis}

End users' stakeholder's attitudes to project sustainability were grouped using statistical analysis of factors to be identified in the literature and expert opinion in achieving the objectives of the research. The data set were assessed for their reliability for the required

Table 1: Characteristics of unstructured interview participants/ respondents

\begin{tabular}{lcccc}
\hline $\begin{array}{l}\text { Description of interview } \\
\text { respondents }\end{array}$ & $\begin{array}{c}\text { Case study "Project } \\
\text { 1" number of } \\
\text { interviews }\end{array}$ & $\begin{array}{c}\text { Case study "Project } \\
\text { 2" number of } \\
\text { interviews }\end{array}$ & $\begin{array}{c}\text { Total number of } \\
\text { interviews } \\
\text { conducted }\end{array}$ & $\begin{array}{c}\text { Average no of } \\
\text { years of using } \\
\text { the PPP road }\end{array}$ \\
\hline $\begin{array}{l}\text { PPP project organisation/company } \\
\text { - Project Engineers }\end{array}$ & 2 & & & \\
- Project Managers & 0 & 1 & 1 & 5.5 years \\
- Consultant & 1 & 2 & 1 & 6.3 years \\
\hline
\end{tabular}


Table 2: Coding data showing challenges facing end-users stakeholders of PPP road project in Nigeria

\begin{tabular}{|c|c|c|c|}
\hline Codes & Respondents & $\begin{array}{l}\text { Comments (from the data, highlighted by the } \\
\text { code) }\end{array}$ & $\begin{array}{l}\text { Measures/themes } \\
\text { (established from the } \\
\text { comment) }\end{array}$ \\
\hline $\begin{array}{l}\text { Drainage and } \\
\text { flooding }\end{array}$ & $\begin{array}{l}R 3 \\
R 1 \\
R 4\end{array}$ & $\begin{array}{l}\text { "This area is worse during the raining season } \\
\text { with flood everywhere because of the drainage } \\
\text { path that was not completed during } \\
\text { construction" } \\
\text { "Look at what happened recently during these } \\
\text { massive flooding it took the state government } \\
\text { over } 24 \text { h to respond to peoples call after their } \\
\text { properties have been destroyed by water due to } \\
\text { heavy downpour, this is not sustainable" } \\
\text { "I think the government should do all the } \\
\text { needful to provide more facilities most } \\
\text { especially in the area of flooding that almost } \\
\text { destroys their properties. The government can } \\
\text { do that by clearing the entire drainage path } \\
\text { along with the road and create more drainage } \\
\text { channels that can accommodate excessive } \\
\text { water" }\end{array}$ & $\begin{array}{l}\text { Improving local } \\
\text { flooding and drainage } \\
\text { works }\end{array}$ \\
\hline Job creation & $\begin{array}{l}R 2 \\
R 4 \\
R 5\end{array}$ & $\begin{array}{l}\text { "Issue of job is another story, is it possible to } \\
\text { give a job of construction to a lay person that } \\
\text { does not have the technicalities? How do they } \\
\text { sustain the job? The answer is capital no but the } \\
\text { indigene is complaining of not giving them jobs } \\
\text { during construction as if we don't want to } \\
\text { comply with their fathers" } \\
\text { "Honestly, the state government even at a stage } \\
\text { compel us to call all the royal fathers in the } \\
\text { community and asked them if they have } \\
\text { anybody that has the experience of what we are } \\
\text { doing on site, but nobody showed up" } \\
\text { "Yes, the good road brought a lot of } \\
\text { development, job opportunities and social life } \\
\text { because there is a cinema inside the shopping } \\
\text { mall that I am working. You don't need to go to } \\
\text { anywhere before you get anything, if this one } \\
\text { can be sustained, I think we're good to go" }\end{array}$ & $\begin{array}{l}\text { Creating jobs for the } \\
\text { residents }\end{array}$ \\
\hline
\end{tabular}

statistical tests using the Cronbach alpha of the data set and also a test Kaiser-Meyer-Olkin (KMO) test of sampling adequacy and Bartlett tests sphericity. Cronbach's alpha coefficient is used in this study to test and examine the reliability of the questionnaire data. Mathematically, Cronbach's alpha is written as follows:

$$
\text { a } 1 / 4 \mathrm{P}_{\mathrm{S}_{\text {criteria }}^{2} \mathrm{P}}^{\mathrm{N}^{2} \mathrm{COV}} \mathrm{COV}_{\text {criteria }}
$$

The test was aimed at checking the regularity of the obtained data to find if the variables and their associated Likert scale are really evaluating the hypothesis they were proposed to measure (Field, 2013). The hypothesis, in this case, is the title given to each number of variables as related to the challenges encountered by the end-users stakeholders in both 
Table 3: End-users-related factors for ensuring the sustainability of PPP projects in host communities

\begin{tabular}{|c|c|}
\hline $\mathrm{S} / \mathrm{N}$ & End-users-related factors for ensuring the sustainability of PPP projects in host communities \\
\hline E1 & Creating jobs for residents \\
\hline E2 & Improving local flooding and drainage works \\
\hline E3 & Royalties for indigenes (compensation) \\
\hline E4 & Repair of local minor roads leading to important places such as market, beaches and other recreational areas \\
\hline E5 & Giving incentives to local residents during road work \\
\hline E6 & Putting proper road work signage in place to increase safety \\
\hline E7 & Avoiding the damage of (or replacing damaged) natural habitats such as water ponds, mangroves and forest \\
\hline E8 & Installation of speed limiting devices on both main and alternative routes \\
\hline E9 & Making provisions for crossing structures \\
\hline E10 & Compensation of electricity for removal of electric poles and overhead cables \\
\hline E11 & Create special crossings for school children \\
\hline E12 & Make effort to reduce cement and other types of dust so as to avoid inhalation by members of the host community \\
\hline E13 & Avoiding displacement and killing of wildlife and endangered speeches \\
\hline E14 & Avoiding local water pollution \\
\hline E15 & Increase restriction efforts on roads during and after construction so as to increase safety \\
\hline E16 & Noise level and air pollution \\
\hline E17 & Providing water wells for communities whose water supply are disrupted due to construction works \\
\hline E18 & Involvement of Community leaders in key decisions \\
\hline E19 & The choice of route for the road in terms of minimal physical effect (e.g. demolition of buildings) on local properties and businesses \\
\hline E20 & Involvement of Residents in key decisions \\
\hline E21 & Reduction of impact to cultural sites \\
\hline E22 & Involvement of Religious leaders in key decisions \\
\hline E23 & Provision of the alternative route during construction to ease traffic \\
\hline E24 & Reduction of disruption of community access \\
\hline E25 & Involvement of private firms within the community in key decisions \\
\hline E26 & Make efforts to stop the increase in the cost of living and provide basic infrastructure \\
\hline E27 & Involvement of Youth leaders in key decisions \\
\hline E28 & Contractor should contribute to the improvement of security in the host community as construction works lead to security risk \\
\hline E29 & Consideration of the community for timings of roadblocks created to carry out construction works \\
\hline E30 & Involvement of Royal fathers in key decisions \\
\hline E31 & Compensations to affected buildings and adjacent areas such as lands, shops and petrol stations \\
\hline E32 & Involvement of Women leaders in key decisions \\
\hline E33 & Travel time during and after construction \\
\hline
\end{tabular}


targeted areas. The coefficient of Cronbach's alpha value ranges from 0 to 1 and as a thumb rule, 0.9 and above represent high consistency, but 0.8 was described as a sign of good internal consistency (reliability) whilst 0.7 is recommended as the lowest acceptable score (George and Mallery, 2003). Table 4 presents the Cronbach's alpha coefficient test results gotten from SPSS. The reliability test was run and the overall Cronbach's alpha coefficient was obtained with variables more than 0.8 portraying good internal consistency of the data.

To check if all the variables are contributing to the internal consistency of the data, the "Cronbach's alpha if item deleted", positioned in column three of Table 4 below is further examined. Based on its rule, any variable that is not contributing to the overall reliability from the sets of variables will generally have a higher value of "Cronbach's alpha if item deleted" than the overall Cronbach's alpha coefficient (Field, 2013). Based on this analysis, five factors that were not contributing to the overall reliability and internal consistency of the data were deleted from the data set. These include as follows: E3 = Royalties for Indigenes as compensation; E10 = Compensation of electricity for removal of electric poles and overhead cables; E13 = Avoiding displacement and killing of wildlife and endangered speeches; E21 = Reduction of impact on cultural sites and E28 = Contractor should contribute to the improvement of security in the host community as construction works lead to security risk. These factors are boldly written in italics in the table below.

\subsection{Exploratory factor analysis for end-users stakeholders challenges along with projectroute}

To ensure that the data is suitable for factor analysis, two important statistical tests were performed. These are KMO test of sampling adequacy and Bartlett tests of sphericity. Whilst the KMO statistic examines the proportion of variable in the variables that is caused by underlying factors which could indicate its suitability for factor analysis (Field, 2013); Bartlett tests examine the existence of any redundancy in the variables that can be summarised with a number of factors (Toriola-Coker et al., 2021). Should the KMO vale be less than 1, this indicates the data may not be entirely measuring the construct (Field, 2013) whilst KMO closer to 1 is generally favoured as a sign of adequacy of the data set for factor analysis. The result of the KMO and Bartlett's statistical tests generated values of 0.793 (above 0.5 ) and 0.0003649747 (less than 0.05 ) as shown in Table 5, signifying that the data set is appropriate for factor analysis and the sampling is satisfactory (Pallant, 2013). According to Pallant (2013), the closer the KMO value to one, the more appropriate the use of factor analysis.

Furthermore, the study needed to explore and ascertain whether the data set contained any underlying structure or variability in correlated items. Hence, series of factor extraction analysis ranging from the "maximum likelihood", "principal component", "generalised least squares" and "principal axis factoring" methods were performed. This was done with the aid of SPSS. They were used in sequence at the initial stage to extract the factors in an attempt to choose the precise number of factors to be extracted. All methods resulted in a total number of eight factor-structure. The factor analysis used a minimum Eigenvalue of 1 to select the underlying factor, but the computation using "maximum likelihood" did not converge at the possible maximum number of iterations for SPSS which is 9,999. This was as SPSS attempted to extract nine factors as shown in Factor Matrix as follows:

Factor Matrix ${ }^{\mathrm{a}}$

$\mathrm{a}=$ Attempted to extract eight factors. In iteration 9,999, no local minimum was found. Extraction was terminated. 
Table 4: Reliability test formotivating factorsfor end-user stakeholders' contribution towardslong-term sustainability of PPPprojects in host communities

\begin{tabular}{|c|c|c|}
\hline $\mathrm{S} / \mathrm{N}$ & Variables & $\begin{array}{l}\text { Cronbach's alpha if } \\
\text { item deleted }\end{array}$ \\
\hline & Overall Cronbach alpha $=0.882$ & \\
\hline E1. & Creating jobs for residents & 0.879 \\
\hline E2. & Improving local flooding and drainage works & 0.880 \\
\hline E3. & Royalties for indigenes (compensation) & 0.885 \\
\hline E4. & Repair of local minor roads leading to important places such as market, beaches and other recreational areas & 0.877 \\
\hline E5. & Giving incentives to local residents during road work & 0.879 \\
\hline E6. & Putting proper road work signage in place to increase safety & 0.874 \\
\hline E7. & Avoiding the damage of (or replacing damaged) natural habitats such as water ponds, mangroves and forest & 0.882 \\
\hline E8. & Installation of speed limiting devices on both main and alternative routes & 0.874 \\
\hline E9. & Making provisions for crossing structures & 0.879 \\
\hline E10. & Compensation of electricity for removal of electric poles and overhead cables & 0.886 \\
\hline E11. & Create special crossings for school children & 0.874 \\
\hline E12. & Make effort to reduce cement and other types of dust so as to avoid inhalation by members of the host community & 0.876 \\
\hline E13. & Avoiding displacement and killing of wildlife and endangered speeches & 0.883 \\
\hline E14. & Avoiding local water pollution & 0.882 \\
\hline E15. & Increase restriction efforts on roads during and after construction so as to increase safety & 0.874 \\
\hline E16. & Noise level and air pollution & 0.877 \\
\hline E17. & Providing water wells for communities whose water supply are disrupted due to construction works & 0.878 \\
\hline E18. & Involvement of community leaders in key decisions & 0.879 \\
\hline E19. & The choice of route for the road in terms of minimal physical effect (e.g. demolition of buildings) on local properties and businesses & 0.879 \\
\hline E20. & Involvement of residents in key decisions & 0.879 \\
\hline E21. & Reduction of impact to cultural sites & 0.883 \\
\hline E22. & Involvement of religious leaders in key decisions & 0.878 \\
\hline E23. & Provision of the alternative route during construction to ease traffic & 0.877 \\
\hline E24. & Reduction of disruption of community access & 0.876 \\
\hline E25. & Involvement of private firms within the community in key decisions & 0.878 \\
\hline E26. & Make efforts to stop the increase in the cost of living and provide basic infrastructure & 0.876 \\
\hline E27. & Involvement of youth leaders in key decisions & 0.877 \\
\hline E28. & Contractor should contribute to the improvement of security in the host community as construction works lead to security risk & 0.885 \\
\hline E29. & Consideration of the community for timings of roadblocks created to carry out construction works & 0.875 \\
\hline E30. & Involvement of royal fathers in key decisions & 0.880 \\
\hline E31. & Compensations to affected buildings and adjacent areas such as lands, shops and petrol stations & 0.878 \\
\hline E32. & Involvement of women leaders in key decisions & 0.880 \\
\hline E33. & Travel time during and after construction & 0.877 \\
\hline
\end{tabular}


Finally, the precise factor extraction that converged was the "principal component" method and "direct oblimin" oblique rotations which were used as methods of factor extraction and rotation, respectively. Having noticed that rotation did not converge with the default 25 iterations setting during the initial extractions, a value of 50 was entered for "maximum iterations for convergence" in the rotation dialogue box. Table 6 below presents the result of the factor analysis.

Results from the factor analysis identified the Top-7 motivating factors influencing endusers towards contributing to the long-term sustainability of PPP projects in the host communities include as follows:

\subsubsection{Safety efforts by the contractor;}

4.1.2 Socio-economic impact;

4.1.3 Benefits realisation and community participation;

4.1.4 Impact on cultural sites;

4.1.5 Environment impact;

4.1.6 Public utility compensation; and

4.1.7 Integration with the host communities.

\section{Discussion of findings}

\subsection{Safety efforts by the contractor}

Based on results from factor analysis, the most important motivating factor influencing end-users towards contributing to the long-term sustainability of PPP projects is "Safety Efforts by the Contractor" with an Eigen value of 7.762. The present tendency is for governmentsand private organisation to assign significant needs to end-users stakeholders who do notunderstand the maintenance of infrastructure (Gangwar and Raghuram, 2015), therebyaccepting sole responsibility creating awareness with guiding principles on sustainability(Ibem and Onyemaechi, 2018). However, this is in accordance with the stakeholder accountability theory, which presumes the allocation of stakeholder welfare between bothparties (Freeman, 2010). These are the crusade that has been repeatedly echoed to theprivate sector so as to morally oblige the end-user stakeholders in project planning.

\subsection{Socio-economic impact}

Going by results from the factor analysis, the second most important motivating factor influencing end-users towards contributing to the long-term sustainability of PPP projects is "Socio-Economic" with an Eigen value of 2.921. Regarding this paper, both Lekki-Epe and Apakun Muritala Muhammed PPP toll roads Project Company in association with the Government did not involve Community Stakeholders throughout the project. At times, the mere fact that private sector companies are taking over government roles may aggravate public resistance $(\mathrm{Ng}$ et al., 2013). Community involvement and consultations from the project area were carried out to support the compilation of the views of end-users

Table 5: KMO and Barlett's

\begin{tabular}{lll}
\hline & KMO and Bartlett's test & \\
\hline $\begin{array}{l}\text { KMO measure of sampling adequacy } \\
\text { Bartlett's test of sphericity }\end{array}$ & Approx. Chi-square & 0.793 \\
\hline
\end{tabular}


Table 6: Extracted factors from factor analysisfor end-users stakeholders

\begin{tabular}{|c|c|c|c|c|c|}
\hline $\mathrm{S} / \mathrm{N}$ & $\begin{array}{l}\text { Motivating factors for end-user stakeholders' contribution towards long- } \\
\text { term sustainability of PPP projects in host communities }\end{array}$ & Factor loading & $\%$ of variance & Eigenvalue & $\begin{array}{l}\text { Factor assigned } \\
\text { name }\end{array}$ \\
\hline & Offspring variables of first extracted factor & & \multirow{7}{*}{23.521} & \multirow{3}{*}{7.762} & \multirow{3}{*}{$\begin{array}{l}\text { Safety efforts by } \\
\text { the contractor }\end{array}$} \\
\hline E1 & Putting proper road work signage in place to increase safety & 0.808 & & & \\
\hline E2 & $\begin{array}{l}\text { Installation of speed limiting devices on both main and alternative routes } \\
\text { during construction }\end{array}$ & 0.730 & & & \\
\hline E3 & Making provisions for crossing structures & 0.446 & & \multirow{9}{*}{2.921} & \multirow{9}{*}{$\begin{array}{l}\text { Socio-economic } \\
\text { impact }\end{array}$} \\
\hline E4 & Create special crossings for school children & 0.574 & & & \\
\hline E5 & $\begin{array}{l}\text { Make effort to reduce cement and other types of dust so as to avoid } \\
\text { inhalation by members of the host community }\end{array}$ & 0.562 & & & \\
\hline E6 & $\begin{array}{l}\text { Increase restriction efforts to the construction site so as to increase safety } \\
\text { Offspring variables of second extracted factor }\end{array}$ & 0.656 & & & \\
\hline E7 & $\begin{array}{l}\text { The choice of route for the road in terms of minimal physical effect (e.g. } \\
\text { demolition of buildings) on local properties and businesses }\end{array}$ & -0.535 & \multirow[t]{5}{*}{8.850} & & \\
\hline E8 & Provision of the alternative route during construction to ease traffic & -0.748 & & & \\
\hline E9 & Reduction of disruption of community access & -0.575 & & & \\
\hline E10 & $\begin{array}{l}\text { Make efforts to stop the increase in the cost of living and provide for basic } \\
\text { infrastructure }\end{array}$ & -0.743 & & & \\
\hline E11 & $\begin{array}{l}\text { Consideration of the community for timings of roadblocks created to carry } \\
\text { out construction works }\end{array}$ & -0.622 & & & \\
\hline E12 & $\begin{array}{l}\text { Compensations to affected building and adjacent areas such as lands, } \\
\text { shops, petrol stations and }\end{array}$ & -0.539 & \multirow{7}{*}{5.694} & \multirow{7}{*}{1.879} & \multirow{7}{*}{$\begin{array}{l}\text { Benefit } \\
\text { realisation and } \\
\text { community } \\
\text { participation }\end{array}$} \\
\hline \multirow[t]{2}{*}{ E13 } & Travel time during and after construction & -0.723 & & & \\
\hline & Offspring variables of third extracted factor & & & & \\
\hline E14 & Creating jobs for residents & 0.675 & & & \\
\hline E15 & Improving local flooding and drainage works & 0.709 & & & \\
\hline E16 & Royalties for indigenes (compensation) & 0.494 & & & \\
\hline E17 & $\begin{array}{l}\text { Repair of local minor roads leading to important places such as market, } \\
\text { beaches and other recreational areas }\end{array}$ & 0.722 & & & \\
\hline E18 & $\begin{array}{l}\text { Giving incentives to local residents during road work } \\
\text { Offspring variables of fourth extracted factor }\end{array}$ & 0.651 & & & \\
\hline E19 & Reduction of impact to cultural sites & 0.674 & 5.415 & 1.787 & $\begin{array}{l}\text { Impact to cultural } \\
\text { sites }\end{array}$ \\
\hline
\end{tabular}




\begin{tabular}{|c|c|c|c|c|c|}
\hline $\mathrm{S} / \mathrm{N}$ & $\begin{array}{l}\text { Motivating factors for end-user stakeholders' contribution towards long- } \\
\text { term sustainability of PPP projects in host communities }\end{array}$ & Factor loading & $\%$ of variance & Eigenvalue & $\begin{array}{l}\text { Factor assigned } \\
\text { name }\end{array}$ \\
\hline & Offspring variables of fifth extracted factor & & & & \\
\hline E20 & $\begin{array}{l}\text { Avoiding the damage of (or replacing damaged) natural habitats such as } \\
\text { water ponds, mangroves and forest }\end{array}$ & 0.863 & 4.414 & 1.457 & $\begin{array}{l}\text { Environmental } \\
\text { impact }\end{array}$ \\
\hline E21 & Avoiding displacement and killing of wildlife and endangered speeches & 0.446 & & & \\
\hline E22 & Avoiding local water pollution & 0.378 & & & \\
\hline \multirow[t]{2}{*}{ E23 } & Noise level and air pollution & 0.308 & & & \\
\hline & Offspring variables of sixth extracted factor & & & & \\
\hline E24 & Compensation of electricity for removal of electric poles and overhead cables & 0.781 & 4.046 & 1.335 & Public utility \\
\hline \multirow[t]{2}{*}{ E25 } & $\begin{array}{l}\text { Providing water wells for communities whose water supply are disrupted } \\
\text { due to construction works }\end{array}$ & 0.398 & & & compensation \\
\hline & Offspring variables of seventh extracted factor & & & & \\
\hline E26 & Involvement of community leaders in key decisions & 0.513 & 3.881 & 1.281 & Integration with \\
\hline E27 & Involvement of residents in key decisions & 0.550 & & & the host \\
\hline E28 & Involvement of private firms within the community in key decisions & 0.377 & & & community \\
\hline E29 & $\begin{array}{l}\text { Involvement of youth leaders in key decisions } \\
\text { Offspring variables of eighth extracted factor }\end{array}$ & 0.343 & & & \\
\hline E30 & Involvement of Royal fathers in key decisions & 0.577 & 3.579 & 1.181 & Integration with \\
\hline E31 & Involvement of women leaders in key decisions & 0.766 & & & political groups \\
\hline E32 & Involvement of religious leaders in key decisions & 0.365 & & & \\
\hline E33 & Involvement of youth leaders in key decisions & 0.427 & & & \\
\hline
\end{tabular}


stakeholders living along with the project road for effective survey computations (Lv and Elgohary, 2016). In addition, unstructured consultations were carried out with transport operators (private cars, public transporters, office workers, amongst others) for interviews. Community leaders, affected men and women were also involved in the discussion on how the PPP road project has directly or indirectly sustained their businesses. The social acceptability of the project was initially unwelcoming given with the potential long and short-term undesirable impacts such as loss of income and properties amongst others (Loosemore and Cheung, 2015).

\subsection{Benefit realisation and community participation}

Going by results from the factor analysis, the third most important motivating factor influencing end-users towards contributing to the long-term sustainability of PPP projects is "Benefits realisation and community participation" with an Eigen value of 1.879. Several authors have shown that capital venture in a PPP road infrastructure project may perform as a facilitator for social transformation and economic growth (Cervero and Kang, 2011; Kim et al., 2014; Neuman and Smith, 2010; Padeiro, 2013). The method of living is changing as the stakeholders in the community areas increases, generating a need for a bigger environment (Atkinson and Blandy, 2013). The findings included the changes that are expected from the built environment which is potentially associated with the new Lekki-Epe and Apakun Muritala Muhammed toll roads. These apprehensions reveal the risks stakeholders perceived concerning the undesirable effect of PPP road infrastructure development. The only potential way of alleviating these fears is to create awareness on how provided infrastructure can be sustained (Pennanen et al., 2013). The prominence of trust in human dealings has been established a long time ago with several research efforts carried out in various disciplines (Padeiro, 2013). The number of local people who could gain employment if properly trained is numerous. This shows that community residents pay more attention to various concerns on the infrastructure development when it happens closer to them and when they presume to have more individual relevance. Financial opportunities for local contractors within the project arena who may be contracted to provide services such as transportation, supply of sand and other construction materials are not trained (Huong et al., 2012). The uses of foreign workers worsen the situation of sustainability knowledge with the local residents, where the end-users stakeholder does not understand the importance of sustainability (Guerra et al., 2012). These situations created dissatisfaction and local frustrations amongst the end-user stakeholders. The failure to hire community artisans during the construction of the toll roads resulted to frustrations at the local level, especially considering that unemployment that was already very high in the neighbourhoods still persists.

\subsection{Mitigating impact on existing local infrastructure}

Going by results from the factor analysis, the fourth most important motivating factor influencing end-users towards contributing to the long-term sustainability of PPP projects is "Impact on cultural sites" with an Eigen value of 1.787. Over the years, large-scale of flooding have been recorded in UK, Mexico, Australia, the USA, Thailand and Brazil (Pedrozo-Acuña et al., 2017). For road infrastructure, high water levels and floods can considerably affect both the lifetime and performance of community stakeholders, as these actions encourage the number of occurrences such as roads being washed away, landslips, submerged and inundated bridge supports, landslides and road closures (Zumrawi, 2016). Hence, sustaining the existing structure (such as roadways) is essential to alleviate the effect of these menaces. Though climate circumstances are usually considered when planning 
transport infrastructure schemes (e.g. road drainage), which can sustain the environmental effect of a community. The two study areas are essentially important for such exercise. The significance of this infrastructure makes it important for end-user stakeholders' participation in sustaining the provided facilities for future use. Upgrading of the road normally causes some temporary changes in drainage systems during the construction phase, particularly where culverts are yet to be replaced or installed (Zumrawi, 2016). The existing drainage path of the two considered project arenas was narrow and upgrading works involved extending the cross-section on both sides of the road which really hampered the movement of community stakeholders. Some of the factors that induced roadway floods can be categorised into social (human-related effects) or natural (rainfall), predominantly heavy rainstorm which is the major cause that trigger and magnify the rare presence of water on road network (Ou-Yang et al., 2015).

\subsection{Mitigating environmental impact of projects on end-users}

Going by results from the factor analysis, the fifth most important motivating factor influencing end-users towards contributing to the long-term sustainability of PPP projects is "Environmental Impact" with the Eigen value of 1.457. Roads construction is a fundamental fragment of modern transportation networks and considerable effort has been done to develop systems that will produce low-cost road alignments through the ideal environment that will integrate several genuine features and limitations (Kang et al., 2012). Nevertheless, roads constructions also affect neighbourhood wildlife inhabitants (Jones et al., 2014; Friedrich, 2015) and in specific circumstances, these effects are the determining factors in final road design selection (Kang et al., 2012). Hence, it is essential to accurately justify for these ecological impacts during the optimisation process of road alignment. Likewise, sustainability of ecological representations can justify for several negative effects of roads construction, they presently emphasis only on overall policy recommendations or existing roads (Friedrich, 2015). As animal inhabitants can be extremely thoughtful to the definite route taken by a road, it is respected that these ecological representations be integrated during the design of a new roadway. This will permit road designers to ascertain original alignments as much as preserving the protracted period of ecological sustainability of new roads along with the project area (Mondal et al., 2015).

\subsection{Ensuring compensation for damage on public utilities}

Going by results from the factor analysis, the sixth most important motivating factor influencing end-users towards contributing to the long-term sustainability of PPP projects is "Public Utilities Compensation" with the Eigen value of 1.335. The residue is the most substantial pollutant from the construction site as it could possibly disturb all the three scopes of sustainability such as social, environmental and economic concurrently ( $\mathrm{Ab}$ Rahman et al., 2010). The developed structure and the economic layout of the project area should be accustomed according to assets, environmental capacity and source of energy (Ahmad et al., 2014). The level of sediments emanated from the construction site is huge, which normally released to water bodies or occupies the whole land (Jeffress et al., 2011). Sediments control facilities and the use of structurally-based erosion are commonly used to reduce the danger of water pollution from the construction site (Teng et al., 2011). The water level of the entire project area is very high, although the normal operations of the road construction were not expected to impend resources the damage of the herbaceous shield following the development of construction sites had affected the surface water regime of the project communities (Armah et al., 2013). Water pollution can be avoided by erecting and installation of control facilities such as dewatering, contour drain, silt fence; flocculation and 
retention ponds (Al-Ani et al., 2014; Ahmad et al., 2014). This influences the risks of quality water (due to pollution as a result of discharge of pollutants and waste water), river sedimentation, soil erosion, stagnation of water in borrow sites, landslides, silting of soils, contamination of the water points used by stakeholders (McPhee and Aird, 2013).

\subsection{Integration with host communities}

Going by results from the factor analysis, the seventh most important motivating factor influencing end-users towards contributing to the long-term sustainability of PPP projects is "integration with host communities" with the Eigen value of 1.281. An incessant development in vehicular traffic in several years back has necessitated the construction of the extension of existing roads or a new road to improve upgraded transportation systems in Nigeria (Babatunde et al., 2016). However, much research has shown influences of either noise or ambient air pollution on health (Basner et al., 2014), insufficient studies have examined the two environmental experiences together. The growth of an environmentally and competent sound transportation network has presumed much better significance in Nigeria in the mission to realise the excellent urban life of end-users stakeholders of a community (Opawole and Jagboro, 2016). Although, for efficient avoidance of health risk it is essential to know whether environmental experiences are influencing health outcomes autonomously and whether impacts of noise and air pollution are co-operative or even protective specifically because of their happening concurrently (Foraster, 2013). Evaluating the environmental effects of such mammoth developmental projects would assist to determine the greater environmental stability and objectives of improved safety for the current and upcoming stakeholders of the community (Chen et al., 2017). Intellectual utility happens to be one of the results that were proposed when traffic noise and air pollution affect any stakeholders (Basner et al., 2014; Block et al., 2012). Air pollution and noise level are the most dangerous impacts that could be expressed during project operation. These are expected and are unavoidable especially during the construction phase of the project even after construction. The environmental effects due to road construction are provisional in nature and these would affect the community stakeholders along with the project arena (Prince et al., 2013). Such effects are affected due to various road construction activities and the movement of earthmoving equipment.

\section{Conclusion and recommendations}

PPP in construction infrastructure has gained significant attention in developing countries following its achievement in the developed countries. To sustain infrastructure for end-user stakeholders, both the government and private investors needed to create awareness that will entail introducing sustainability practices into the built environment and construction programmes in the Nigeria communities. This paper has delved into factors for enabling the contribution of end-user stakeholder's in the helping to sustaining Nigeria's PPP road projects in the long-term. The study found safety efforts by the contractors; the social economic impact of the project; and benefit realisation vis-à-vis community participation are at the top three factors at the core of strategies that can help end-users key into sustaining PPP projects in Nigeria's host communities in the long-term. The study concluded that creating jobs for residents; Improving local flooding and drainage works; Repair of minor local roads; Avoid damaging of (or replacing damaged) natural habitats; Avoiding local water pollution and Noise level and air pollution are factors that will enhance the end-user stakeholders of the community to participate in sustainably maintaining PPP projects in their communities. Based on the above findings, the following recommendations can be made for key stakeholders that the need to include sustainability strategies right from the design and its inclusion in the contract cannot be underestimated especially in Nigeria and in other part of the world where contract dictates the tune on how construction projects are delivered. Additionally, motivations (financial and non-financial) are vital for improving the practice of sustainable construction. For 
example, the government can create awareness right from the wards, local government and state level on sustainable strategies. The findings of the current study contribute to the existing body of knowledge on the barriers to SCP from the context of the Nigerian construction industry. Although the current study is limited to the view of construction stakeholders and practitioners in the Lagos metropolis, the study provides valuable insights on the strategies reducing stakeholder opposition to PPP projects and factors motivating their long-term buy-in towards ensuring maintainability and long-term sustainability of projects in host communities.

\section{References}

Abel, F., Herder, E., Houben, G.J., Henze, N. and Krause, D. (2013), "Cross-system user modeling and personalization on the social web", User Modeling and User-Adapted Interaction, Vol. 23 Nos 2/3, pp. 169-209.

Ab Rahman, N.N., Omar, F.M. and Ab Kadir, M.O. (2010), "Environmental aspects and impacts of construction industry", Impact, Monitoring and Management of Environmental Pollution.

Ahmad, H., Miller, J.W. and George, R.D. (2014), "Minimizing pond size using an off-site pond in a closed basin: a storm flow mitigation design and evaluation", International Journal of Sustainable Development and Planning, Vol. 9 No. 2, pp. 211-224.

Al-Ani, R.R., Al Obaidy, A.H.M.J. and Badri, R.M. (2014), "Assessment of water quality in the selected sites on the tigris river, Baghdad-Iraq", International Journal of Advanced Research, Vol. 2 No. 5, pp. 1125-1131.

Akintoye, A., Liyanage, C.L. and Renukappa, S. (2011), “ARCOM doctoral workshop proceedings on 'Public private partnerships".

Amadi, C.J. (2017), "A framework for stakeholder management in Public-Private partnership (PPP) projects", Doctoral dissertation, Loughborough University.

Armah, F.A., Luginaah, I.N., Taabazuing, J. and Odoi, J.O. (2013), "Artisanal gold mining and surface water pollution in Ghana: have the foreign invaders come to stay?", Environmental Justice, Vol. 6 No. 3 , pp. 94-102.

Arnstein, S.R. (2015), "A ladder of citizen participation", The City Reader, Vol. 279

Atkinson, R. and Blandy, S. (Eds). (2013), Gated Communities: International Perspectives, Routledge. New York, NY.

Babatunde, S.O., Perera, S., Zhou, L. and Udeaja, C. (2016), "Stakeholder perceptions on critical success factors for public-private partnership projects in Nigeria", Built Environment Project and Asset Management, Vol. 6 No. 1, pp. 74-91.

Bai, L., Li, Y., Du, Q. and Xu, Y. (2017), "A fuzzy comprehensive evaluation model for sustainability risk evaluation of PPP projects", Sustainability, Vol. 9 No. 10, p. 1890.

Basner, M., Babisch, W., Davis, A., Brink, M., Clark, C., Janssen, S. and Stansfeld, S. (2014), "Auditory and non-auditory effects of noise on health", The Lancet, Vol. 383 No. 9925, pp. 1325-1332.

Block, M.L., Elder, A., Auten, R.L., Bilbo, S.D., Chen, H., Chen, J.C. and Gold, D.R. (2012), "The outdoor air pollution and brain health workshop", NeuroToxicology, Vol. 33 No. 5, pp. 972-984.

Carbonara, N., Costantino, N. and Pellegrino, R. (2016), "A transaction costs-based model to choose PPP procurement procedures", Engineering, Construction and Architectural Management, Vol. 23 No. 4 , pp. 491-510.

Cervero, R. and Kang, C.D. (2011), "Bus rapid transit impacts on land uses and land values in Seoul", Transport Policy, Vol. 18 No. 1, pp. 102-116.

Chen, H., Kwong, J.C., Copes, R., Tu, K., Villeneuve, P.J., Van Donkelaar, A., .. . Wilton, A.S. (2017), "Living near major roads and the incidence of dementia, parkinson's disease, and multiple sclerosis: a population-based cohort study", The Lancet, Vol. 389 No. 10070, pp. 718-726. 
Chung, D., Hensher, D.A. and Rose, J.M. (2010), “Toward the betterment of risk allocation: Investigating risk perceptions of Australian stakeholder groups to public-private-partnership toll road projects", Research in Transportation Economics, Vol. 30 No. 1, pp. 43-58.

Delmon, J. (2017), Public-Private Partnership Projects in Infrastructure: An Essential Guide for Policy Makers, Cambridge university press. Cambridge.

Du, J., Wu, H. and Zhao, X. (2018), "Critical factors on the capital structure of public-private partnership projects: a sustainability perspective", Sustainability, Vol. 10 No. 6, p. 2066.

Fatokun, A., Akintoye, A. and Liyanage, C.L. (2015), "Renegotiation of public private partnership road contracts: Issues and outcomes",

Field, A. (2013), Discovering Statistics Using IBM SPSS Statistics, Sage. New York, NY.

Foraster, M. (2013), "Is it traffic-related air pollution or road traffic noise, or both? Key questions not yet settled!",

Freeman, R.E. (2010), Strategic Management: A Stakeholder Approach, Cambridge University Press. Cambridge.

Friedrich, J. (2015), "Integrating neglected ecological impacts of road transport into corporate management", Ecological Indicators, Vol. 54, pp. 197-202.

Gangwar, R. and Raghuram, G. (2015), "Framework for structuring public private partnerships in railways", Case Studies on Transport Policy, Vol. 3 No. 3, pp. 295-303.

George, D. and Mallery, M. (2003), "Using SPSS for windows step by step: a simple guide and reference",

Greenfield, E.A. (2015), "Healthy aging and age-friendly community initiatives", Public Policy and Aging Report, Vol. 25 No. 2, pp. 43-46.

Greenfield, E.A., Oberlink, M., Scharlach, A.E., Neal, M.B. and Stafford, P.B. (2015), "Age-friendly community initiatives: conceptual issues and key questions", The Gerontologist, Vol. 55 No. 2, pp. 191-198.

Guerra, E., Cervero, R. and Tischler, D. (2012), "Half-mile circle: does it best represent transit station catchments?", Transportation Research Record: Journal of the Transportation Research Board, Vol. 2276 No. 1, pp. 101-109.

Hashim, R.G., Sharif, M.S.M., Muhammad, R. and Aminuddin, Z.M. (2020), "Sustainable campus income generation initiative and social entrepreneurship at a public university", EnvironmentBehaviour Proceedings Journal, Vol. 5 No. 13, pp. 293-297.

Ibem, E.O. and Onyemaechi, P.C. (2018), "Project selection and transparency factors in housing publicprivate partnerships in Nigeria", Construction Economics and Building, Vol. 18 No. 2, pp. 15-40.

Jeffress, M.R., Paukert, C.P., Whittier, J.B., Sandercock, B.K. and Gipson, P.S. (2011), "Scale-dependent factors affecting North American river otter distribution in the Midwest", The American Midland Naturalist, Vol. 166 No. 1, pp. 177-193.

Johnson, R.B. and Gray, R. (2010), "A history of philosophical and theoretical issues for mixed methods research", Sage Handbook of Mixed Methods in Social and Behavioral Research, Vol. 2, pp. 69-94.

Kang, C.K., Moon, J.Y., Lee, S.I. and Jablonski, P.G. (2012), "Camouflage through an active choice of a resting spot and body orientation in moths", Journal of Evolutionary Biology, Vol. 25 No. 9, pp. 1695-1702.

Ke, Y., Hao, W., Ding, H. and Wang, Y. (2017), "Factors influencing the private involvement in urban rail public-private partnership projects in China", Construction Economics and Building, Vol. 17 No. 1.

Kim, S., Park, S. and Lee, J.S. (2014), "Meso-or micro-scale? Environmental factors influencing pedestrian satisfaction", Transportation Research Part D: Transport and Environment, Vol. 30, pp. 10-20.

Loosemore, M. and Cheung, E. (2015), "Implementing systems thinking to manage risk in public private partnership projects", International Journal of Project Management, Vol. 33 No. 6, pp. 1325-1334. 
Lv, X. and El-Gohary, N. (2016), "Text analytics for supporting stakeholder opinion mining for largescale highway projects", Procedia Engineering, Vol. 145, pp. 518-524.

McPhee, J.E. and Aird, P.L. (2013), "Controlled traffic for vegetable production: Part 1. Machinery challenges and options in a diversified vegetable industry", Biosystems Engineering, Vol. 116 No. 2, pp. 144-154.

Mondal, S., Lucet, Y. and Hare, W. (2015), "Optimizing horizontal alignment of roads in a specified corridor", Computers and Operations Research, Vol. 64, pp. 130-138.

Mwakabole, G.C., Gurmu, A.T. and Tivendale, L. (2019), "Investigation of the challenges facing publicprivate partnership projects in Australia", Construction Economics and Building, Vol. 19 No. 1.

Mwakibinga, F.A. and Buvik, A. (2013), "An empirical analysis of coercive means of enforcing compliance in public procurement", Journal of Public Procurement, Vol. 13 No. 2, pp. 243-273.

Mwelu, N., Davis, P.R., Ke, Y. and Watundu, S. (2018), "Compliance within a regulatory framework in implementing public road construction projects", Construction Economics and Building, Vol. 18 No. 4.

Neuman, M. and Smith, S. (2010), "City planning and infrastructure: once and future partners", Journal of Planning History, Vol. 9 No. 1, pp. 21-42.

Ng, S., Lingard, L. and Kennedy, T.J. (2013), "Qualitative research in medical education: methodologies and methods", Understanding Medical Education: Evidence, Theory and Practice, Vol. 1, pp. 371-384.

Norouzian-Maleki, S., Bell, S., Hosseini, S.B. and Faizi, M. (2015), "Developing and testing a framework for the assessment of neighbourhood liveability in two contrasting countries: Iran and Estonia", Ecological Indicators, Vol. 48, pp. 263-271.

Olson, B. and Swenson, D. (2011), "Overtime effects on project team effectiveness", The Midwest Instruction and Computing Symposium.

Opawole, A. and Jagboro, G.O. (2016), "Benchmarking parties' obligations in the execution of concession-based PPP projects in Nigeria", Journal of Place Management and Development, Vol.9 No. 1.

Ou-Yang, B., Chu, C.C., Da, Y.B., Liu, X.F. and Zhang, H.Y. (2015), "Highway flood disaster risk evaluation and management in China", Natural Hazards, Vol. 75, pp. 381-397.

Oyedele, L.O. (2012a), "Avoiding performance failure payment deductions in PFI/PPP projects: model of critical success factors", Journal of Performance of Constructed Facilities, Vol. 27 No. 3, pp. 283-294.

Oyedele, O.A. (2012b), "Public-Private partnership (PPP) and infrastructure provision in Nigeria", AARCHES 2012 Biennial General Meeting and Annual Conference.

Padeiro, M. (2013), "Transport infrastructures and employment growth in the paris metropolitan margins", Journal of Transport Geography, Vol. 31, pp. 44-53.

Pallant, J. (2013), SPSS Survival Manual: A Step by Step Guide to Data Analysis Using IBM SPSS (5. Uppl), McGraw-Hill Maidenhead.

Pedrozo-Acuña, A., Moreno, G., Mejía-Estrada, P., Paredes-Victoria, P., Breña-Naranjo, J.A. and Meza, C. (2017), "Integrated approach to determine highway flooding and critical points of drainage", Transportation Research Part D: transport and Environment, Vol. 50, pp. 182-191.

Pennanen, K., Tiilikainen, A. and Viitanen, K. (2013), "Exploring ways to successful resident-driven infill development: lessons learned from two cases in Helsinki area", Proceedings of SB13 Oulu on Sustainable Procurement in Urban Regeneration and Renovation.

Prince, M., Bryce, R., Albanese, E., Wimo, A., Ribeiro, W. and Ferri, C.P. (2013), "The global prevalence of dementia: a systematic review and metaanalysis", Alzheimer's and Dementia, Vol.9 No. 1, pp. 63-75.

Teng, Y., Yang, J., Zuo, R. and Wang, J. (2011), "Impact of urbanization and industrialization upon surface water quality: a pilot study of panzhihua mining town", Journal of Earth Science, Vol. 22 No. 5, p. 658.

Toriola-Coker, O.L. (2018), "End-user stakeholders' management framework for public private partnership road project in Nigeria", Doctoral dissertation, University of Salford. 
Toriola-Coker, L.O., Agbali, M. and Adeniran, W. (2021), "Proposed framework for effective management of End-User stakeholders' in public private partnership road projects in Nigeria".

Toriola-Coker, L.O., Alaka, H., Agbali, M., Bello, W.A., Pathirage, C. and Oyedele, L. (2020), "Marginalization of end-user stakeholder's in public private partnership road projects in Nigeria", International Journal of Construction Management, Vol. 1, pp. 1-10.

Tunji-Olayeni, P., Kajimo-Shakantu, K. and Osunrayi, E. (2020), "Practitioners' experiences with the drivers and practices for implementing sustainable construction in Nigeria: a qualitative assessment", Smart and Sustainable Built Environment, Vol. 9 No. 4.

Whang, S.W. and Kim, S. (2015), "Balanced sustainable implementation in the construction industry: the perspective of Korean contractors", Energy and Buildings, Vol. 96, pp. 76-85.

Xiao, R., Harrison, C. and Hudson, S.E. (2013), "WorldKit: rapid and easy creation of ad-hoc interactive applications on everyday surfaces", Proceedings of the SIGCHI Conference on Human Factors in Computing Systems. ACM, pp. 879-888.

Zawawi, N.A.W.A., Ahmad, M., Umar, A.A., Khamidi, M.F. and Idrus, A. (2014), "Financing PF2 projects: opportunities for Islamic project finance", Procedia Engineering, Vol. 77, pp. 179-187.

Zhang, S., Teizer, J., Lee, J.K., Eastman, C.M. and Venugopal, M. (2013), "Building information modeling (BIM) and safety: automatic safety checking of construction models and schedules", Automation in Construction, Vol. 29, pp. 183-195.

Zumrawi, M.M. (2016), "Investigating surface drainage problem of roads in Khartoum state", International Journal of Civil Engineering and Technology (IJCIET), Vol. 7 No. 3, pp. 91-103.

Further reading

Adeniyi, O., Aje, I.O. and Ogunsemi, D.R. (2011), "Strengths, weaknesses, opportunities, and threats for public-private partners in infrastructure delivery in Nigeria", Journal of Construction Project Management and Innovation, Vol. 1 No. 2, pp. 130-154.

Agbelie, B.R. (2014), "An empirical analysis of three econometric frameworks for evaluating economic impacts of transportation infrastructure expenditures across countries", Transport Policy, Vol. 35, pp. 304-310.

Aghimien, D.O., Adegbembo, T.F., Aghimien, E.I. and Awodele, O.A. (2018), "Challenges of sustainable construction: a study of educational buildings in Nigeria", International Journal of Built Environment and Sustainability, Vol. 5 No. 1.

Beighley, R.E., Scholl, B., Faucette, L.B. and Governo, J. (2010), "Runoff characteristics for construction site erosion control practices", Journal of Irrigation and Drainage Engineering, Vol. 136 No. 6, pp. 405-413.

Belayutham, S., Gonzalez, V.A. and Yiu, T.W. (2016), "A cleaner production-pollution prevention based framework for construction site induced water pollution", Journal of Cleaner Production, Vol. 135, pp. 1363-1378.

Bosher, L. (2014), "Built-in resilience through disaster risk reduction: operational issues", Building Research and Information, Vol. 42 No. 2, pp. 240-254.

Bolomope, M.T., Awuah, K.G.B., Amidu, A.R. and Filippova, O. (2020), "The challenges of access to local finance for PPP infrastructure project delivery in Nigeria", Journal of Financial Management of Property and Construction, Vol. 26 No. 1.

Bradley, G. (2016), Benefit Realisation Management: A Practical Guide to Achieving Benefits through Change, CRC Press. London.

Braun, V. and Clarke, V. (2013), Successful Qualitative Research: A Practical Guide for Beginners, Sage. New York, NY.

Breese, R. (2012), “Benefits realisation management: panacea or false dawn?", International Journal of Project Management, Vol. 30 No. 3, pp. 341-351. 
Brocklebank, P. (2014), Private Sector Involvement in Road Financing. SSATP 2014, The World Bank Group, New York, NY.

Camilleri, E. (2012), Project Success: critical Factors and Behaviours, Gower Publishing, Ltd. Hampshire.

Chaharbaghi, K. and Willis, R. (1999), "The study and practice of sustainable development", Engineering Management Journal, Vol. 9 No. 1, pp. 41-48.

Cheung, E. (2009), "Developing a best practice framework for implementing public private partnerships (PPP) in Hong Kong", PhD Thesis. Queensland University of Technology, Queensland.

Clark, C., Crombie, R., Head, J., Van Kamp, I., Van Kempen, E. and Stansfeld, S.A. (2012), "Does trafficrelated air pollution explain associations of aircraft and road traffic noise exposure on children's health and cognition? A secondary analysis of the United Kingdom sample from the RANCH project", American Journal of Epidemiology, Vol. 176 No. 4, pp. 327-337.

Dania, A.A. (2017), "Sustainable construction at the firm level: case studies from Nigeria", (Doctoral dissertation, University of Reading.

Dolla, T. and Laishram, B. (2019), "Prequalification in municipal solid waste management publicprivate partnerships of India", Construction Economics and Building, Vol. 19 No. 1.

Doloi, H. (2009), "Analysis of pre-qualification criteria in contractor selection and their impacts on project success", Construction Economics and Building, Vol. 27 No. 12, pp. 1245-1263.

EIU (The Economist Intelligence Unit) (2015), Evaluating the Environment for Public-Private Partnerships in Africa: The 2015 Infrascope, EIU, London.

Eliasson, J. and Lundberg, M. (2012), "Do cost-benefit analyses influence transport investment decisions? Experiences from the swedish transport investment plan 2010-21", Transport Reviews, Vol. 32 No. 1, pp. 29-48.

Emecheta, G.N. (2010), "Public-Private partnership: challenges and prospects",

Farreny, R., Gabarrell, X. and Rieradevall, J. (2011), "Cost-efficiency of rainwater harvesting strategies in dense mediterranean neighbourhoods”, Resources, Conservation and Recycling, Vol. 55 No. 7, pp. 686-694.

Feldman, P.M., Bahamonde, R.A. and Velasquez Bellido, I. (2014), "A new approach for measuring corporate reputation”, Revista de Administração de Empresas, Vol. 54 No. 1, pp. 53-66.

Garlan, D., Dwivedi, V., Ruchkin, I. and Schmerl, B. (2012), "Foundations and tools for end-user architecting", Monterey Workshop, Springer, Berlin, Heidelberg pp. 157-182.

Green, J., Willis, K., Hughes, E., Small, R., Welch, N., Gibbs, L. and Daly, J. (2007), "Generating best evidence from qualitative research: the role of data analysis", Australian and New Zealand Journal of Public Health, Vol. 31 No. 6, pp. 545-550.

Guxens, M. and Sunyer, J. (2012), "A review of epidemiological studies on neuropsychological effects of air pollution”, Swiss Medical Weekly, Vol. 141 No. 0102.

Hare, W., Hossain, S., Lucet, Y. and Rahman, F. (2014), "Models and strategies for efficiently determining an optimal vertical alignment of roads", Computers and Operations Research, Vol. 44, pp. 161-173.

Huong, N.T.T. (2012), "Trends of urbanization and suburbanization in southeast asia", Trends of Urbanization and Suburbanization in Southeast Asia, Vol. 325.

ICRC; Infrastructure Concession Regulatory Commission (2018), PPP in Nigeria is Regulated by ICRC to Improve Development, ICRC, Abuja. available at: www.icrc.gov.ng/ (accessed 11 July 2020).

ICRC (2020), PPP Contract Disclosure Portal: Key to Improvement of Infrastructure Deficit in Nigeria. ICRC, Abuja. available at: www.icrc.gov.ng/ppp-contract-disclosure-portal-key-improvementinfrastructure-deficit-nigeria/(accessed 11 July 2020).

Jang, G.W. (2010), "Bids-evaluation decision model development and application for PPP transport projects: a project risks modeling framework", The. 2000-2019-CSU Theses and Dissertations.

Jang, S. (2011), "A concessionaire selection decision model development and application for the PPP project procurement", Doctoral dissertation, University of Southampton. 
Joseph, G.S., Seymour, C.L., Cumming, G.S., Cumming, D.H. and Mahlangu, Z. (2014), "Termite mounds increase functional diversity of woody plants in african savannas", Ecosystems, Vol. 17 No. 5, pp. 808-819.

Kenley, R. (2014), "Productivity improvement in the construction process",

Kenley, R. and Harfield, T. (2014), "Location breakdown structure (LBS): a solution for construction project management data redundancy", Proceedings of the International Conference on Construction in a Changing World, pp. 4-7.

Labelle, F. and Leyrie, C. (2013), "Stakepartner management" in projects. A turn-of-the-century turnaround at Alcan", The Journal of Modern Project Management, Vol. 1 No. 1.

Li, Q., Fan, H., Luan, X., Yang, B. and Liu, L. (2014), "Polygon-based approach for extracting multilane roads from OpenStreetMap urban road networks", International Journal of Geographical Information Science, 28(11), 2200-2219.

Lossa, E. and Martimort, D. (2013), "Corruption in public-private partnerships", The Routledge Companion to Public Private Partnerships, Routledge New York, NY, pp. 205-255.

Lutt, F. (2018), in Benfield, F.K (Ed.). People Habitat: 25 Ways to Think about Greener, Healthier Cities, People Habitat Communications: Washington, DC.

Marsal-Llacuna, M.L., Colomer-Llinàs, J. and Meléndez-Frigola, J. (2015), "Lessons in urban monitoring taken from sustainable and livable cities to better address the smart cities initiative", Technological Forecasting and Social Change, Vol. 90, pp. 611-622.

Mikolaj, J., Trojanova, M. and Pepucha, L. (2012), International Federation of Municipal Engineering Conference Proceedings. Helsinki.

Mishra, S., Kang, M.W. and Jha, M.K. (2014), "Empirical model with environmental considerations in highway alignment optimization", Journal of Infrastructure Systems, Vol. 20 No. 4.

Mohammadpour, A., Karan, E., Asadi, S. and Rothrock, L. (2015), "Measuring end-user satisfaction in the design of building projects using eye-tracking technology", Computing in Civil Engineering, Vol. 1, pp. 564-571.

Neal, J., Villanueva, I., Wright, N., Willis, T., Fewtrell, T. and Bates, P. (2012), "How much physical complexity is needed to model flood inundation?", Hydrological Processes, Vol. 26 No. 15, pp. 2264-2282.

Newton, P. and Glackin, S. (2014), "Understanding infill: towards new policy and practice for urban regeneration in the established suburbs of australia's cities", Urban Policy and Research, Vol. 32 No. 2, pp. 121-143.

Nijkamp, P. and Blaas, E.W. (2012), Impact Assessment and Evaluation in Transportation Planning, Springer Science and Business Media. New York, NY.

Nwoye, C.F. and Iyiola, O. (2016), "An assessment of the carrying capacity of Lagos metropolitan roads: a case study of Mile2-Apapa and Lekki-Epe corridors", Arts and Social Sciences Journal, Vol. 7 No. 1, pp. 1-8.

Obayelu, A.E. (2018), "Public-private partnerships for inclusive agribusiness sustainability in Africa", Agriculturae Conspectus Scienti $\mathbf{f} u s$, Vol. 83 No. 3, pp. 251-261.

Olawale, O.A., Oyedele, L.O. and Owolabi, H.A. (2020), "Construction practitioners' perception of key drivers of reputation in mega-construction projects", Journal of Engineering, Design and Technology, Vol. 18 No. 6.

Östlund, U., Kidd, L., Wengström, Y. and Rowa-Dewar, N. (2011), "Combining qualitative and quantitative research within mixed method research designs: a methodological review", International Journal of Nursing Studies, Vol. 48 No. 3, pp. 369-383.

Pemsel, S. and Müller, R. (2012), "The governance of knowledge in project-based organizations", International Journal of Project Management, Vol. 30 No. 8, pp. 865-876.

Pemsel, S. and Wiewiora, A. (2013), "Project management office a knowledge broker in project-based organisations", International Journal of Project Management, Vol. 31 No. 1, pp. 31-42.

Pemsel, S., Widén, K. and Hansson, B. (2010), "Managing the needs of end-users in the design and delivery of construction projects", Facilities, Vol. 28 Nos 1/2. 
Rana, F. and Chidi, I. (2018), "Infrastructure and Africa's development - the PPP imperative", World Bank Group Getting Infrastructure Finance Right available at: https://blogs.worldbank.org/ppps/ infrastructure-africa-s-development-ppp-imperative\#comment-225856 (accessed 11 July 2020).

Schraven, D., Hartmann, A. and Dewulf, G. (2011), "Effectiveness of infrastructure asset management: challenges for public agencies", Built Environment Project and Asset Management, Vol. 1 No. 1.

Serra, C.E.M. and Kunc, M. (2015), "Benefits realisation management and its influence on project success and on the execution of business strategies", International Journal of Project Management, Vol. 33 No. 1, pp. 53-66.

Solheim-Kile, E., Lædre, O., Lohne, J. and Meland, Ø.H. (2014), "Characteristics of public-private partnerships in Norway", in Kalsaas, B.T., Koskela, L. and Saurin, T.A. (Eds), pp. 559-569.

Soomro, M.A. and Zhang, X. (2013), "Failure links between public and private sector partners in transportation public private partnerships failures", Journal of Traffic and Logistics Engineering, Vol. 1 No. 2, pp. 116-121.

Tzivian, L., Winkler, A., Dlugaj, M., Schikowski, T., Vossoughi, M., Fuks, K., .. . Hoffmann, B. (2015), "Effect of long-term outdoor air pollution and noise on cognitive and psychological functions in adults", International Journal of Hygiene and Environmental Health, Vol. 218 No. 1, pp. 1-11.

Vandenbossche, J. and Demuynck, T. (2013), "Network formation with heterogeneous agents and absolute friction", Computational Economics, Vol. 42 No. 1, pp. 23-45.

Van Troost, D., Van Stekelenburg, J. and Klandermans, B. (2013), "Emotions of protest", In Emotions in Politics, Palgrave Macmillan, London, pp. 186-203.

Velasco-Elizondo, P., Dwivedi, V., Garlan, D., Schmerl, B. and Fernandes, J.M. (2013, June), "Resolving data mismatches in end-user compositions", International Symposium on End User Development, Springer, Berlin, Heidelberg pp. 120-136.

Wainger, L. and Mazzotta, M. (2011), "Realizing the potential of ecosystem services: a framework for relating ecological changes to economic benefits", Environmental Management, Vol. 48 No. 4, p. 710 .

Wong, P.S. and Maric, D. (2016), "Causes of disputes in construction planning permit applications", Journal of Legal Affairs and Dispute Resolution in Engineering and Construction, Vol. 8 No. 4.

World Bank Group (2016), "Public-private partnerships in infrastructure toolkit informed decisionmaking", World Bank Group available at: http://pubdocs.worldbank.org/en/982261479317855835/ InfrastructureToolkit-Booklet-FINALWEB.pdf

Yang, J., Shen, G.Q., Ho, M., Drew, D.S. and Xue, X. (2011), "Stakeholder management in construction: an empirical study to address research gaps in previous studies", International Journal of Project Management, Vol. 29 No. 7, pp. 900-910.

Zwikael, O. and Smyrk, J. (2011), Project Management for the Creation of Organisational Value, Springer. London. 